\title{
ULUSLARARASI ANDLAŞMALARIN GEÇİCİ UYGULANMASI - VIYANA ANDLAŞMALAR HUKUKU SÖZLEŞMESİ 25. MADDE
}

\author{
PROVISIONAL APPLICATION OF TREATIES - ARTICLE 25 OF \\ THE VIENNA CONVENTION ON THE LAW OF TREATIES
}

DOI: $10.21492 /$ inuhfd. 443456

Elif UZUN*

\begin{abstract}
Özet
Viyana Andlaşmalar Hukuku Sözleşmesi'nin 25. maddesi, taraflar mutabık kaldığ takdirde, bir andlaşmanın, yürürlüğe girmeden önce geçici olarak uygulanabileceğini belirtir. Bunun anlamı, yürürlüğe girmesi için iç hukukta bazı işlemlerin yapılması gereken bir andlaşmanın bu iç hukuk prosedürünün tamamlanmasından önce uygulanmaya başlayabilmesidir. $\mathrm{Bu}$ hükmün, uluslararası örf ve âdet hukukunun kodifiye edilmesi anlamına geldiği kabul edilmektedir. Ne var ki gerek 25. madde gerekse çok taraflı andlaşmalardaki geçici uygulama hükümleri kimi zaman uluslararası ihtilaflara neden olabilmektedir. Bu ihtilafların nedeni genellikle andlaşmayı geçici uygulamayı ilk başta kabul etmiş devletlerin andlaşmayı geçici uyguladıkları dönemde ortaya çıkan uluslararası sorumluluktan kurtulma isteğidir. Diğer yandan VAHS 25. maddedeki ve çok taraflı andlaşmalardaki geçici uygulama hükümlerindeki bazı açıklığa kavuşmamış hususlar da ihtilaflara neden olabilmektedir. Bu makale Türkçede incelenmemiş bu konuyu ve konu hakkındaki uluslararası hukuk literatürünü betimsel bir yaklaşımla ele almaktadır. Bu teorik düzeydeki anlatıma ilaveten, geçici uygulama hakkında tartışma yaratan bazı uluslararası ihtilaflar ve Uluslararası Hukuk Komisyonu'nun halihazırda yürüttügü çalışma kısaca ele alınacaktır.
\end{abstract}

Anahtar Kelimeler: Uluslararası andlaşmalar hukuku, andlaşmaların geçici uygulanması, Viyana Andlaşmalar Hukuku Sözleşmesi

\footnotetext{
Abstract

Article 25 of the Vienna Convention on the Law of Treaties (VCLT) confirms that a treaty may be applied provisionally pending its entry into force if negotiating states have agreed on it. This means that a treaty, which needs the completion of internal law procedures to enter into force, can be applied before its entry into force. This provision is accepted as the codification of international customary law. Yet Article 25 and provisional application clauses in multilateral treaties may give rise to international disputes. Behind such disputes is generally a desire of the states, having first agreed to apply the treaty provisionally, to subsequently avoid their treaty obligations under provisional application.

* Doç. Dr., Anadolu Üniversitesi, Hukuk Fakültesi, Milletlerarası Hukuk Anabilim Dalı. (E-mail: eluzun@anadolu.edu.tr), (ORCID: 0000-0001-7825-7840)

Makale Gönderilme Tarihi: 13.07.2018 Article Submitted Date: 13.07.2018

Makale Kabul Tarihi: 23.10.2018 Article Accepted Date: 23.10.2018
} 
The aim of this article is to examine a topic which has attracted little or no interests in the Turkish doctrine, thereby turning its attention to the international literature for a primarily descriptive study. In so doing, it will also briefly analyse pertinent international disputes predicated upon wider academic discussions on provisional application of treaties as well as the ongoing work of the International Law Commission.

Keywords: Law of treaties, provisional application of treaties, Vienna Convention on the Law of Treaties

\section{GİRIŞ}

Andlaşmalar, uluslararası hukukun en önemli kaynă̆ıdır. Özellikle Birleşmiş Milletler'in kuruluşundan sonra çok taraflı uluslararası andlaşmaların sayısında yaşanan artış, andlaşmaların uluslararası hukukun kaynağı olmak bakımından önemini büyük ölçüde artırmıştır. Bugün için 1969 Viyana Andlaşmalar Hukuku Sözleşmesi (VAHS), uluslararası andlaşmalar hukukunun otorite sahibi metni olarak karşımıza çıkmaktadır. Sözleşme bu otoritesini sadece çok taraflı bir andlaşma olmasından ve Sözleşme'yle bağlanan devletlerin sayısından almamaktadır; VAHS aynı zamanda andlaşmalar hukuku alanındaki örf ve âdet hukukunu da kodifiye etmiştir. Dolayısıyla andlaşmalar hukuku araştırma ve tartışmalarının merkezinde VAHS bulunmaktadır.

$\mathrm{Bu}$ makale, uluslararası andlaşmalar hukukunun aynı zamanda VAHS'de de karşıllı̆ı olan bir sorununa odaklanmaktadır: Andlaşmaların geçici uygulanması. VAHS'nin 25. maddesi uyarınca, taraflar anlaştıkları takdirde, andlaşmanın tamamı veya bir kısmı, andlaşmanın yürürlüğe girmesinden önce uygulanmaya başlayabilmektedir. 25. maddenin ikinci fikrası ise, andlaşmayla bağlanmama iradesini bildiren devlet açısından geçici uygulamanın sona ereceğini hükme bağlamıştır.

Türkçe literatürde geçici uygulama konusunda neredeyse hiçbir incelemenin bulunmadığı gerçeğinden yola çıkılarak, bu makalede, geçici uygulamaya yönelik ağırlıklı olarak betimsel bir inceleme sunulacaktır. $\mathrm{Bu}$ çerçevede VAHS temelinde geçici uygulamanın kapsamına, unsurlarına ve hukuki sonuçlarına ilişkin uluslararası hukuk literatürünün genel yaklaşımı sunulacaktır. Konu ele alınırken, geçici uygulamanın merkezde olduğu güncel sayılabilecek bazı uluslararası hukuk uyuşmazlıklarına da değinilecek, son olarak Uluslararası Hukuk Komisyonu'nun (UHK) yürütmekte olduğu geçici uygulama çalışmasının hâlihazırdaki durumu kısaca özetlenecektir.

\section{GEÇİCI UYGULAMA: TANIM VE TERMINOLOJİ}

Uluslararası hukukun kaynağ1 olarak andlaşmalar her geçen gün önemini artırmaktadır. Devletlerin uluslararası hukuk uyarınca sahip 
olduğu yükümlülükler bir taraftan uluslararası örf ve âdet hukukunun kodifiye edilmesiyle, diğer taraftan ise devletlerin akdettikleri iki ve çok taraflı andlaşmalar yoluyla uluslararası andlaşmalarda daha çok görünür hâle gelmektedir'. Bu açıdan andlaşmaların "uluslararası hukuktaki en önemli yükümlülük kaynağı" olduğu söylenebilir². Sahip olduğu bu konum ve uluslararası hukukun kaynakları arasındaki artan öneminin sonucu olarak uluslararası andlaşmalar hukuku gittikçe daha çok önem kazanmakta, andlaşmalar hukuku kavram ve kurumları daha çok tartışma konusu olmaktadir.

Bir uluslararası andlaşma, "uluslararası hukukun kendilerine bu alanda yetki tanıdığı kişiler arasında, uluslararası hukuka uygun bir biçimde, hak ve yükümlülükler doğuran, bunları değiştiren ya da sona erdiren yazılı irade uyuşması" dır $^{3}$. Normal şartlarda bir andlaşmanın uygulanmaya başlaması için tarafların andlaşmayla bağlanması ve andlaşmanın yürürlüğe girmesi gerekir. Andlaşmanın uygulanması açısından tarafların sorumlu tutulabilmesi de bu yolla olur.

Andlaşmalar hukuku alanındaki örf ve âdet hukukunu kodifiye eden Viyana Andlaşmalar Hukuku Sözleşmesi'nin ${ }^{4}$ (VAHS) 11. maddesine göre, "Bir Devletin bir andlaşma ile bağlanma rızası imza, bir andlaşma teşkil eden belgelerin teatisi, onay, kabul, tasvip veya katılma veya üzerinde mutabık kalındiysa diğer herhangi bir araçla açıklanabilir". Dolayısıyla, yetkili bile olsalar temsilcilerin imzaladığı andlaşmayla bağlanabilmek için, imzacı devletlerin iç hukukta gerçekleştirilmesi gereken eylemler bulunmaktadır. Bir andlaşmanın müzakerelerine katılmış, andlaşmayı imzalamış olmak, andlaşmayla bağlanma işlemlerini sonlandırma yükümlülüğü doğurmaz. Andlaşmayı imzalamış olan devlet pekâlâ andlaşmayla bağlanmayabilir ${ }^{5}$. Andlaşmayı imzalamış olan devlet iç hukuk uyarınca gerekli prosedürü başlatmayabileceği gibi, iç hukuk prosedürü sonunda andlaşmayla bağlanmama iradesi ortaya çıkabilir.

${ }^{1}$ Bkz. Yusuf AKSAR, Teoride ve Uygulamada Uluslararası Hukuk - I, 3. bask1 (Ankara: Seçkin Yayıncılık, 2015), s. 101.

2 James CRAWFORD, Brownlie's Principles of Public International Law, 8. bask1 (Oxford: OUP, 2012), s. 30.

${ }^{3}$ Hüseyin PAZARCI, Uluslararası Hukuk Dersleri - 1. Kitap, 12. bask1 (Ankara: Turhan Kitabevi, 2014), s. 111.

4 Vienna Convention on the Law of Treaties, 1969. Türkçesi: Aslan GÜNDÜZ, Milletleraras1 Hukuk (İstanbul: Beta Basım Yayım, 1998), ss. 182-205. Orijinal metin: $<$ https://treaties.un.org/doc/publication/unts/volume\%201155/volume-1155-i-18232english.pdf> (03.07.2018).

5 Martin A. ROGOFF ve Barbara E. GAUDITZ, "The Provisional Application of International Aggreements", Maine Law Review, C. 39, 1987, s. 34. 
Nitekim VAHS 11. maddede sayılan onay, kabul ve tasvip bağlanma yöntemleri, imza sonrasında devletlerin iç hukuk uyarınca ek bir işlem yapmasını gerektirir.

Andlaşmanın uygulanmaya başlanması için ise, andaşmanın yürürlüğe girmiş olması gerekir. VAHS'nin 'Yürürlüğe girme' başlıklı 24. maddesinin ilgili hükümleri şu şekildedir:

"1. Bir andlaşma, kendisinin öngördüğü veya görüşmeci Devletlerin mutabık kalabilecekleri tarzda ve tarihte yürürlüğe girer.

2. Böyle bir hüküm veya mutabakat yoksa, andlaşma bütün görüşmeci Devletler için andlaşma ile bağlanma rızası tespit edilir edilmez yürürlüğe girer.

3. Andlaşmanın yürürlüğe girmesinden sonraki bir tarihte bir Devletin andlaşma ile bağlanma rızasını açıklaması halinde, andlaşma aksini öngörmedikçe, o Devlet bakımından andlaşma o tarihte yürürlüğe girer."

Andlaşmaların bağlayıcıllğı için bağlanma ve yürürlüğe girme bu hayati öneme sahip olsa da VAHS md. 25 yürürlüğe girme öncesinde de andlaşmanın uygulanabileceğine dair hüküm içermektedir. Anılan maddenin birinci fikrası şu şekildedir:

"1. Bir andlaşma veya bir andlaşmanın bir bölümü a- andlaşmanın kendisi öngörürse veya

b- görüşmeci Devletler başka bir tarzda böyle mutabık kalırlarsa, andlaşma yürürlüğe girinceye kadar geçici olarak uygulanır."

Maddeye göre, andlaşmada öngörülmesi veya tarafların başka bir vasitayla bu yönde mutabik kalması durumunda, andlaşma veya andlaşmanın bir kısmı, andlaşmalar hukukunun ve bizzat andlaşmanın kendisinin öngördüğü yürürlüğe girme koşulları gerçekleşmeden önce uygulanmaya başlayacaktır. Dolayısıyla ortada henüz yürürlüğe girmemiş bir andlaşmanın uygulanmaya başlaması, böylece ilgili devletler açısından ${ }^{6}$ yükümlülük ve sorumluluk doğurması söz konusudur.

${ }^{6} 1986$ Viyana Devletlerle Uluslararası Örgütler veya Uluslararası Örgütlerle Uluslararası
Örgütler Arasındaki Andlaşmalar Hukuku Sözleşmesi’nin 25. maddesi de aynı
formülasyona sahiptir. Bkz. Vienna Convention on Treaties between States and
International Organizations or between International Organizations (1986), U.N. Doc.
A/CONF.129/15
(1986). <http://legal.un.org/ilc/texts/instruments/english/conventions/1_2_1986.pdf> (06.07.2018). 
İlk bakışta tuhaf yahut paradoksal gelebilecek bu uygulama ${ }^{7}$ esasında örf ve adet hukukundan kaynaklanmaktadır. Gerçi VAHS'nin hazırlanması esnasına uygulamayı destekleyen opinio juris'in varlığından bahsedilmese ve UHK'deki ve Viyana Konferansı'ndaki çalışmalarda somut devlet pratiği gündeme getirilmemiş olsa da genel kanaat 25 . maddenin ilk fikrasının örf ve âdet hukukunun yansıması olduğu yönündedir ${ }^{8}$. Nitekim devlet uygulamasına dair pek çok örnek de vermek mümkündür? .

$\mathrm{Bu}$ noktada hatırlatmamız gereken bir husus VAHS md. 25'in ikinci fikrasıyla ilgilidir. İkinci fikraya göre,

"Andlaşma başka türlü öngörmedikçe veya görüşmeci Devletler başka türlü mutabık kalmadıkça, bir andlaşmanın veya bir andlaşmanın bir bölümünün bir Devlet bakımından uygulanmasına, o Devlet, aralarında geçici olarak andlaşmanın uygulandığı diğer Devletleri andlaşmaya taraf olmamak hususundaki niyetinden haberdar ederse, son verilecektir".

$\mathrm{Bu}$ fikrayla örf ve âdet hukuku kodifiye edilmemiş olup, andlaşmalar hukukuna yeni bir hüküm getirilmiştir ${ }^{10}$.

VAHS md. 25'in başlığında ve hükmün kendisinde kullanılan ifadenin 'geçici uygulama' olduğuna işaret etmemiz gerekiyor ${ }^{11}$. UHK'nin

7 Tuhaflık yahut paradoksal oluş şuradan kaynaklanmaktadır: Bir yanda yürürlüğe girmediği halde uygulanan ve hukuki sonuç doğuran bir andlaşma bulunmakta, diğer yanda ise hukuki sonuç doğurduğu halde onay, katılma gibi usullerle andlaşmayla bağlanılması beklenmektedir. Bkz. ROGOFF ve GAUDITZ, "The Provisional Application of International Aggreements", s. 41.

${ }^{8}$ Denise MATHY, "1969 Vienna Convention - Article 25", The Vienna Conventions on the Law of Treaties, Ed.: O. CORTEN ve P. KLEIN (Oxford: OUP, 2011), s. 640-1.

${ }^{9}$ Geçici uygulamanın 1648 Westphalia Barış Andlaşması'ndan itibaren örnekleri için bkz. Robert E. DALTON, "Provisional Application of Treaties", The Oxford Guide to Treaties, Ed.: Duncan B. HOLLIS (Oxford: OUP, 2012), s. 222-6.

${ }^{10}$ MATHY, "1969 Vienna Convention - Article 25", s. 641; Heike KRIEGER, "Artice 25", Vienna Convention on the Law of Treaties, Ed.: O. DÖRR ve K. SCHMALENBACH (Berlin-Heidelberg: Springer-Verlag, 2012), s. 412. VILLIGER ayırım yapmaksızın md. 25'in örf ve âdet hukukunu yansıttığını söyler: Mark. E. VILLIGER, Commentary on the 1969 Vienna Convention or the Law of Treaties (Lieden ve Boston: Martinus Nijhoff Publishers, 2009), s. 357.

11 Metnin İngilizce orijinalinde kullanılan kelime 'provisional'dır. Kelimenin geçici dışında 'koşullu', 'koşula bağlı' anlamları da mevcuttur. Türkçe metinlerde üzerinde durulması gerekli olmamakla birlikte, konunun terminolojik olarak incelendiği çalışmalarda ve VAHS'nin UHK'deki hazırlanış sürecinde, 'provisional' kelimesinin hukuki etkiler açısından değil (yani koşula bağlılık değil) zaman açısından anlam taşıdığı 
VAHS ile ilgili yürüttüğü çalışmalarda raportörler 'geçici yürürlüğe girme' ifadesini kullanmış, bu kullanıma bazı üyeler ciddi itiraz etmesine rağmen Viyana Konferansı'na gönderilen metin 'geçici yürürlüğe girme' ifadesini muhafaza etmişti. Bununla birlikte Konferans'ta yapılan tartışmalar sonucunda 'geçici uygulama' ifadesi benimsenmiştir. Yine de uluslararası andlaşmalar hukuku ile ilgili önemli metin ve çalışmalarda zaman zaman 'geçici uygulama'ya karşl1ık gelmek üzere 'geçici yürürlüğe girme’ ifadesinin kullanıldığına rastlamak mümkündür ${ }^{12}$.

Bu hâliyle 'geçici uygulama' ifadesi, genel itibariyle andlaşmaların yürürlüğe girmesi ile uygulanması arasındaki farkı da yansıtır. Zira andlaşmaların yürürlüğe girmesi ile andlaşmanın tamamının veya bir kısmının uygulanmaya başlaması aynı âna denk gelir. Kimi zaman ise andlaşmanın bazı hükümleri andlaşmanın yürürlüğe girmesinden sonra uygulanmaya başlanır. Yani andlaşma yürürlüğe girmiş ancak hükümlerinin tamamının veya bir kısmının uygulanmaya başlaması için andlaşmada öngörülen bir koşulun (olay veya süre) gerçekleşmesi beklenmektedir. Bunun yanında andlaşmaların bazı hükümleri kimi zaman andlaşma yürürlüğe girmeden önce uygulanmaya başlar. VAHS md. 24(4) uyarınca,

"Bir andlaşma metninin tevsiki, Devletlerin andlaşma ile bağlanma rızasının tespit edilmesi, yürürlüğe giriş tarzı veya tarihi, çekinceler, depoziter makamının işlevleri ve andlaşmanın yürürlüğe girmesinden önce zorunlu olarak ortaya çıkan diğer meseleleri düzenleyen hükümleri, andlaşma metninin kabulü zamanından itibaren uygulanır."

Dolayısıyla andlaşmanın yürürlüğe girmesi ile hükümlerinin uygulanması her zaman aynı durumu ifade etme ${ }^{13}$.

\section{GEÇICI UYGULAMANIN LEH VE ALEYHINDEKI GÖRÜŞLER}

Gerek Viyana Konferansı'nda gerek devlet uygulamalarında gerekse literatürde geçici uygulamanın tercih edilmesi için öne sürülen en

üzerinde de durulmak zorunda kalınmıştır. Ör. bkz. VILLIGER, Commentary on the 1969 ..., s. 354.

${ }^{12}$ MATHY, "1969 Vienna Convention - Article 25", s. 647; Anneliese Quest MERTSCH, Provisionally Applied Treaties: Their Binding Force and Nature (Lieden ve Boston: Brill, 2012), s. 3.

${ }^{13}$ MERTSCH, Provisionally Applied Treaties..., s. 12. 
önemli gerekçe 'aciliyet'tir ${ }^{14}$. Bilhassa çok taraflı andlaşmalar söz konusu olduğunda andlaşmanın yürürlüğe girmesi için imza dışında ek işlemler yapılması gerekmekte, bu ek işlemlerin tamamlanarak andlaşmanın yürürlüğe girmesi kimi zaman andlaşmanın imzalanmasından yıllar sonra gerçekleşebilmektedir. Ne var ki kimi andlaşmalar konuları itibariyle acilen uygulanmayı gerektirmekte, geçici uygulama opsiyonu andlaşmanın resmî olarak yürürlüğe girinceye kadar olan sürede, söz konusu acil ihtiyacın karşılanmasını sağlamaktadır. Aciliyet özellikle çatışmaları sonlandıran andlaşmalar söz konusu olduğunda gündeme gelmektedir ${ }^{15}$. Bunun yanında doğal afetlerle ilgili andlaşmalarda da aciliyet nedeniyle geçici uygulama hükümlerine ihtiyaç duyulduğu söylenebilir. Örneğin 26 Nisan 1986'da Çernobil Nükleer Santrali'nde meydana gelen kaza sonrasında 26 Eylül 1986'da imzalanan Nükleer Kaza veya Radyolojik Acil Hallerde Yardımlaşma Sözleşmesi ile Nükleer Kaza Halinde Erken Bildirim Sözleşmesi ${ }^{16}$ geçici uygulama ile ilgili bir hüküm içermektedir ${ }^{17}$.

Geçici uygulama lehindeki gerekçelerden bir başkası, geçici uygulamanın sağladığı esnekliktir. Andlaşmaların çoğunca uzun süren onaylanma süreçlerinin tamamlanmasına gerek kalmadan uygulanmaya başlaması, andlaşmalar hukukunun daha esnek kullanılması olarak görülmüştür ${ }^{18}$.

Geçici uygulamanın lehinde belirtilen görüşler arasında, hassas konularda yapılmış andlaşmalar için bu uygulamanın bir tür önlem niteliği

${ }^{14}$ MATHY, "1969 Vienna Convention - Article 25", s. 643; DALTON, "Provisional Application of Treaties", s. 234; MERTSCH, Provisionally Applied Treaties..., s. 9; Juan Manuel GÓMEZ-ROBLEDO, First Report on the Provisional Application of Treaties, BMGK A/CN.4/664, 2013, <http://undocs.org/en/A/CN.4/664> (12.06.2018). par. 27; René LEFEBER, "Treaties, Provisional Application", The Max Planck Encyclopedia of Public International Law, C. X, Ed.: R. WOLFRUM (Oxford: OUP, 2012), par. 1.

${ }^{15}$ KRIEGER, “Article 25”, s. 408; GÓMEZ-ROBLEDO, First Report on the Provisional Application of Treaties, par. 27;

16 Her iki sözleşme için: R.G., T. 03.09.1990, S. 20624. Metin için bkz. <https://www.tbmm.gov.tr/tutanaklar/KANUNLAR_KARARLAR/kanuntbmmc073/kan untbmmc073/kanuntbmmc07303610.pdf> (12.06.2018).

${ }^{17}$ Nükleer Kaza veya Radyolojik Acil Hallerde Yardımlaşma Sözleşmesi’nin 15., Nükleer Kaza Halinde Erken Bildirim Sözleşmesi'nin ise 13. maddesi şu şekildedir: "Herhangi bir Devlet imza sırasında veya bu Sözleşmenin kendisi için yürürlüğe girmesinden önceki herhangi bir tarihte, bu Sözleşmeyi geçici olarak uygulayacağını beyan edebilir."

18 MATHY, "1969 Vienna Convention - Article 25", s. 643; DALTON, "Provisional Application of Treaties", s. 234; GÓMEZ-ROBLEDO, First Report on the Provisional Application of Treaties, par. 28-30;. 
taşıdığı da dile getirilmektedir ${ }^{19}$. Tarafların pozisyonlarından ödün vermek durumunda kaldıkları andlaşmalar söz konusu olduğunda, andlaşmanın yürürlüğe girmesi için gereken usuli işlemlerin yapılmasına dek geçen sürede bu hassasiyetlerin gözetilmesi gerekmektedir. Bu yönüyle geçici uygulama, VAHS md. 18 hükmünün bir tamamlayıcısı olarak iş görür. VAHS md. 18 'e göre, bir andlaşmayı imzalayan devlet, andlaşma yürürlüğe girinceye veya andlaşmaya taraf olmama niyetini beyan edene kadar "andlaşmanin konu ve amacını ortadan kaldıracak hareketlerden kaçınmak mecburiyetindedir". İşte geçici uygulama da bu mecburiyeti güçlendirerek $^{20}$ tarafların andlaşma yürürlüğe girinceye kadar pozisyonlarını korumasını sağlamaya hizmet edebilmektedir. Nitekim Avrupa'da Konvansiyonel Silahlı Kuvvetler Antlaşması'nın Bazı Hükümlerinin Geçici Olarak Uygulanması Hakkındaki Protokol ${ }^{21}$ tam da bu amaca hizmet etmektedir ${ }^{22}$.

Geçici uygulamanın taraftar bulan gerekçelerinden bir başkası, geçici uygulama ile yaratılan andlaşma rejimlerine geçişin kolaylaştırılmasıdır. Andlaşma hükümlerinin bir kısmının geçici uygulama vasıtasıyla andlaşmanın tamamı fiilen yürürlüğe girmeden önce uygulanmaya başlanarak farklı andlaşma rejimleri arasında oluşabilecek hukuki boşlukların önüne geçilmiş de olacaktır ${ }^{23}$.

Geçici uygulama aleyhine ileri sürülen az sayıdaki görüşten birisi, böyle bir uygulamanın iç hukuk veya anayasal düzen ile uluslararası hukuk arasında bir çatışmaya neden olabileceğidir ${ }^{24}$. Geçici uygulamaya dair ileri sürülen bir başka itiraz ise, geçici uygulamanın iç hukuk uyarınca gerekli onaylama prosedürünün devre dışı bırakılması için bir

${ }^{19}$ KRIEGER, “Article 25”, s. 409; GÓMEZ-ROBLEDO, First Report on the Provisional Application of Treaties, par. 31; LEFEBER, "Treaties, Provisional Application", par. 1.

${ }^{20}$ GÓMEZ-ROBLEDO, First Report on the Provisional Application of Treaties, par. 31.

${ }^{21}$ R.G. $\quad 26.6 .1992, \quad$ S. $21266 . \quad$ Metin için bkz. <https://www.tbmm.gov.tr/tutanaklar/KANUNLAR_KARARLAR/kanuntbmmc075/kan untbmmc075/kanuntbmmc07503818.pdf> (12.06.2018).

22 KRIEGER, “Article 25”, s. 409; GÓMEZ-ROBLEDO, First Report on the Provisional Application of Treaties, par. 31.

${ }^{23}$ KRIEGER, “Article 25”, s. 410; MATHY, "1969 Vienna Convention - Article 25”, s. 643; LEFEBER, “Treaties, Provisional Application”, par. 1; GÓMEZ-ROBLEDO, First Report on the Provisional Application of Treaties, par. 33.

${ }^{24}$ MATHY, "1969 Vienna Convention - Article 25”, s. 643; GÓMEZ-ROBLEDO, First Report on the Provisional Application of Treaties, par. 35. 
hile olarak kullanılmaya açık olmasıdır ${ }^{25}$. İç hukukla ilgili bu itirazları bir sonraki başılık altında daha ayrıntılı bir şekilde ele alacağız.

\section{GEÇİCI UYGULAMA VE İÇ HUKUK}

Geçici uygulamanın leh ve aleyhindeki görüşlere bakıldığında, uygulama lehindeki görüşlerin uluslararası hukuk açısından dile getirildiğini, aleyhteki görüşlerin ise iç hukuk açısından söz konusu olduğu görülmektedir. Çünkü, tekrarlayacak olursak, geçici uygulama ulusal hukukların gerektirdiği onay süreçleri tamamlanmaksızın andlaşmaların kısmen veya tamamen uygulanabilmesine olanak tanımaktadır. Özellikle güçler ayrılığının belirgin olduğu devletler söz konusu olduğunda, andlaşmayı imzalamaya yetkili kişi veya organların işlemlerinin iç hukuk açısından bu imzayı denetlemeye yetkili organlar tarafından geçersiz kılınma riski bulunmaktadır. Sözgelimi, Türk hukuku açısından, Anayasa md. 90 uyarınca, "Türkiye Cumhuriyeti adına yabancı devletlerle ve milletlerarası kuruluşlarla yapilacak andlaşmaların onaylanması, Türkiye Büyük Millet Meclisinin onaylamayı bir kanunla uygun bulmasına bağlıdır". Bu kurala tabi olmayan istisna grubu andlaşmaların varlığına rağmen, yine Anayasanın aynı hükmü uyarınca, "Türk kanunlarına değişiklik getiren her türlü andlaşmaların yapılmasında birinci fikra hükmü uygulanır"26. Benzer uygulamalara sahip devletler açısından, kanunlarda değişiklik getiren veya bütçe uygulamalarına aykırılık teşkil andlaşmaların geçici uygulama ile uygulanma imkanı, en azından iç hukuka uygun davranan devlet yetkilileri açısından imkansız hâle gelmektedir ${ }^{27}$.

İç hukuk ile uluslararası taahhütler arasında yaşanabilecek çelişkilerden kaçınmanın bir yolu ise, geçici uygulamanın sonuç doğurmasını iç hukuktaki düzenlemeler veya akdedilen andlaşmalar ile ilgili andlaşmanın iç hukuktaki prosedürünün tamamlanması koşuluna

${ }^{25}$ KRIEGER, “Article 25”, s. 412; MATHY, “1969 Vienna Convention - Article 25”, s. 643; GÓMEZ-ROBLEDO, First Report on the Provisional Application of Treaties, par. 35 .

${ }^{26}$ Türk hukukunda andlaşmalara taraf olma usulü hakkında ayrıntılı bilgi için bkz. AKSAR, Teoride ve Uygulamada Uluslararası Hukuk - I, s. 178-82; PAZARCI, Uluslararası Hukuk Dersleri - 1. Kitap, s.167; Yücel ACER ve İbrahim KAYA, Uluslararası Hukuk Temel Ders Kitabı, 6. baskı (Ankara: Seçkin Yayıncılık, 2015), s. 85-7; Enver BOZKURT, M. Akif KÜTÜKÇÜ ve Yasin POYRAZ, Devletler Hukuku, 7. baskı (Ankara: Yetkin Yayınları, 2012), s. 72-77; Toluner Milletlerarası Hukuk (Giriş, Kaynaklar), Der.: A.N. TÜTÜNCÜ vd. (İstanbul: Beta, 2017), s. 162-6.

${ }^{27}$ LEFEBER, “Treaties, Provisional Application”, par. 15. 
bağlanmasıdır ${ }^{28}$. Başka bir ifade ile, geçici uygulamanın bağlayıcı hâle gelmesi için taraf devletin iç hukuktaki aşamaları tamamlaması gerekli görülebilir. Bu durumda her ne kadar geçici uygulamanın talep ettiği acil uygulama söz konusu olmasa da, özellikle yürürlüğe girmesi uzun süre alan uluslararası andlaşmaların en azından andlaşmaya taraf olmuş devletlerce kısmen veya tamamen uygulanmaya başlanması imkanı ortaya çıkmış olur. Uluslararası andlaşmalarda böyle bir seçenek sunulmasının nedeni, devletlerin geçici uygulamayı yasaklayacak veya ayrıntılı düzenleyecek iç hukuk kuralları yaratmasını önlemektir ${ }^{29}$. Devletlerin geçici uygulama hükümlerinden tümden kaçınmasını engellemenin bir başka yolu ise, geçici uygulamanın iç hukuklara tabi kılınmasıdır. Geçici uygulamayı iç hukuka tabi kılan andlaşma hükümlerine uluslararası hukuk literatüründe 'sınırlama kaydı' (limitation clause) adı verilir ${ }^{30}$. Böylece andlaşmayı kısmen veya tamamen geçici uygulamakta olan devletin iç hukuku ile uygulanmakta olan adlaşma hükümleri arasında bir çatışma çıktığında iç hukukun üstün geleceği kabul edilmiş olur ${ }^{31}$.

Tam da bu noktada geçici uygulamanın iç hukuklarla ilişkisi açısından sıklıkla atıf yapılan iki tahkim kararına, Kardassopoulos ve Yukos kararlarına değinmemiz gerekiyor. Her iki dava da Enerji Şartı Anlaşmast $^{32}$ (EŞA) çerçevesinde ortaya çıkmıştır.

EŞA "enerji sektöründe uluslararası işbirliğini destekleyen çok taraflı ilk belge"dir ${ }^{33}$. Anlaşma'nın 45. maddesi geçici uygulamaya ilişkindir. Maddenin ilk fikrasına göre;

"Her bir imzacı bu Anlaşmayı, Anlaşma 44. Maddeye uygun şekilde kendisi için yürürlüğe girinceye dek $^{34}$-böyle bir geçici

${ }^{28}$ KRIEGER, “Article 25”, s. 417; MATHY, “1969 Vienna Convention - Article 25”, s. 645.

${ }^{29}$ KRIEGER, “Article 25”, s. 417.

${ }^{30}$ MERTSCH, Provisionally Applied Treaties..., s. 73.

${ }^{31}$ KRIEGER, “Article 25”, s. 418; MATHY, "1969 Vienna Convention - Article 25”, s. 645.

32 Enerji Şartı Anlaşması - Energy Charter Treaty (ECT), 17 Aralık 1994, Lizbon. Türkiye Anlaşma'nın tarafıdır: R.G. 12 Temmuz 2000, S. 24107. Orijinal metin için bkz. Energy Charter Secreteriat, The Energy Charter Treaty and Related Documents, 2004, Belçika. İnternet erişimi: $<$ http://www.ena.lt/pdfai/Treaty.pdf > (404.07.2018).

${ }^{33}$ P. BAKLACI ve Esen AKINTÜRK, "Enerji Şartı Anlaşması", Dokuz Eylül Üniversitesi İşletme Fakültesi Dergisi, C. 7, S. 2, 2006, s. 98.

${ }^{34}$ Anlaşma'nın 44. maddesi uyarınca Anlaşma otuzuncu devletin onay, kabul, tasvip veya katılım belgesini Depozitör'e tesliminden doksan gün sonra yürürlüğe girecek, bundan sonra onay, kabul, tasvip veya katılım belgesini gönderen devlet açısından ise o devletin belgeyi göndermesinden doksan gün sonra yürürlüğe girecektir. 
uygulama kendi anayasası, yasaları veya düzenlemeleri ile uyumsuz olmadığı ölçüde- geçici olarak uygulama konusunda fikir birliğine varmıştır". İkinci fikranın (a) bendine göre ise, "Birinci fikra hükümlerine rağmen her bir imzacı, imza esnasında, Depozitör'e geçici uygulamayı kabul edemeyeceğini belirten bir beyanı teslim edebilir. Birinci fikrada yer alan yükümlülük böyle bir beyanda bulunmuş olan imzacıya tatbik edilemez. Böyle bir imzacı beyanını Depozitör'e sunacağı bir bildirimle her zaman geri çekebilir"35.

$\mathrm{Bu}$ hükümler uyarınca EŞA'nın imzacılar tarafından, vazgeçme yönünde beyanda bulunmadıkları sürece, geçici olarak uygulanacağı görülmektedir. İmzaci devletleri geçici uygulamadan çekilmekten alıkoymak üzere tasarlanmış bir başka hüküm, aynı maddenin ikinci fikrasının (b) bendinde yer almaktadır. Buna göre, bir devlet EŞA'yı geçici olarak uygulamayacağını beyan ederse, ne kendisi ne de bu devletten yatırımcılar geçici uygulamaya dayanarak hak talep edebilecektir.

ICSID'de verilen 6 Temmuz 2007 tarihli Kardassopoulos hakemlik kararına yol açan olaylarda bir Yunan yatırımeı Kardassopoulos, Gürcistan Cumhuriyeti'nin, daha önce verdiği bir enerji imtiyazını 19951997 arasında verdiği kararlarla kamulaştırarak kendisini zarara uğrattığını iddia etmiştir. Yunanistan ve Gürcistan Aralık 1994'te EŞA'yı imzalamış, Anlaşma her iki devlet için de 1998 Nisan'ında, EŞA md. 44'te öngörülen usul ve süre sonunda yürürlüğe girmiştir ${ }^{36}$. Kardassopoulos'un iddiasına göre Gürcistan 1994'te EŞA'yı imzalamakla

\footnotetext{
${ }^{35}$ Anlaşmanın bu hükümlerinin çevirisi tarafımdan yapılmıştır. İngilizcesi şu şekildedir; Birinci fikra: "Each signatory agrees to apply this Treaty provisionally pending its entry into force for such signatory in accordance with Article 44, to the extent that such provisional application is not inconsistent with its constitution, laws or regulations." İkinci fikranın (a) bendi: "(a) Notwithstanding paragraph (1) any signatory may, when signing, deliver to the Depository a declaration that it is not able to accept provisional application. The obligation contained in paragraph (1) shall not apply to a signatory making such a declaration. Any such signatory may at any time withdraw that declaration by written notification to the Depository." Geçici uygulamayı ele alan Türkçe iki makale, Resmî Gazetedeki çevirisini esas alarak konuyu incelemiştir. Bkz. Bağdagül KAYA CANER, "Enerji Şartı Anlaşmasının Muvakkaten Uygulanması ve Anlaşmadan Çekilme Hakkında Bir Değerlendirme", Ankara Barosu Dergisi, 2014/3, s 324; İslam Safa KAYA, "Uluslararası Andlaşmalardan Çekilme Hakkı ve Uluslararası Andlaşmaların Geçici Uygulanması: Enerji Şartı Andlaşması Örneği”, The Journal of Academic Social Science Studies, N. 44, Spring II, 2016, s. 198-9.

${ }^{36}$ Matthew BELZ, "Provisional Application of the Energy Charter Treaty: Kardassopoulos v. Georgia and Improving Provisional Application in Multilateral Treaties", C. 22, Emory International Law Review, 2008, s. 739.
} 
Anlaşma'yı tümden uygulama yükümlülügü altına girmiştir. Bu iddianın dayanağı, EŞA md. 45'teki geçici uygulama kaydıdır. Gürcistan ise EŞA md. 45'in sadece bir temenniden ibaret olduğunu iddia etmiştir. Gürcistan'a göre, eğer md. 45 bir temenniyi dile getirmiyorsa bile, maddede atıf yapılan iç hukuka uygunluk dikkate alınmalıdır. Bu durumda da hem Yunan hem de Gürcü hukuku geçici uygulamaya izin vermemektedir $^{37}$. Dolayısıyla EŞA, henüz yürürlüğe girmediği dönemde, Gürcistan açısından bağlayıcı değildir. Hakemlik mahkemesi Kardassopoulos lehine karar vermiştir. Mahkeme maddede yer alan geçici uygulamayı bir temenni olarak değil, hukuki hak ve yükümlülükler yaratan bir ifade olarak görmüş ${ }^{38}$, geçici uygulamanın uluslararası hukukta hak ve yükümlülük yaratan bir kurum olduğuna karar vermiş ${ }^{39}$, iki ülkenin iç hukuklarının da geçici uygulamayla uyumsuz olmadığını tespit etmiş ${ }^{40}$, dolayısıyla Gürcistan'ın imzaladığı tarihten itibaren EŞA'yı uygulamakla yükümlü olduğunu belirtmiştir ${ }^{41}$.

EŞA'nın geçici uygulamaya dair bu hükümlerinin tartışmanın merkezine oturduğu davalardan bir başkası olan Yukos davas ${ }^{42}$ Rusya Federasyonu'na karşı açılmıştır. Sovyetler Birliği'nin dağılmasının ardından özelleştirilen ancak bir süre hisseleri yine devlete ait kalan enerji alanında faaliyet gösteren Yukos şirketinin \%51 hissesi, 1995 ve 1996 yıllarındaki hisse satışlarıyla Cebelitarık merkezli, iki Rus yatırımcının önderliğindeki bir grup yatırımcıya ait olan bir şirket tarafından satın alınır. İç siyasetin etkili olduğu bir sürecin sonunda Yukos'un ortakları çeşitli nedenlerle tutuklanır, şirket aleyhine vergi cezaları kesilir, Yukos'un yan şirketleri satışa çıkarılır. Bunun üzerine Rusya Federasyonu'na önce EŞA'nın şart koştuğu dostane çözüm için

${ }^{37}$ Kardassopoulos v. Georgia, Decision on Jurisdiction, 6 Temmuz 2007, ICSID (W. Bank), Case No. ARB/05/18, par. 73.

${ }^{38}$ Kardassopoulos v. Georgia, Decision on Jurisdiction, par. 209.

${ }^{39}$ Kardassopoulos v. Georgia, Decision on Jurisdiction, par. 223.

${ }^{40}$ Kardassopoulos v. Georgia, Decision on Jurisdiction, par. 224-46.

${ }^{41}$ Karar andlaşmaların yorumu ve EŞA'nın başka hükümleriyle de ilgili pek çok hususu içermektedir ve farklı açılardan eleştiri konusu yapılmıştır. Eleştiri için ör. bkz. BELZ, "Provisional Application of the Energy Charter Treaty...", s. 742-9.

${ }^{42}$ Literatürde ve medyada siklıkla tek bir dava gibi atıf yapılan Yukos davasında esasında ortada üç dava vardır. Davalar birbirleriyle ilişkili, aynı tarafa yönelmiş, arka arkaya açılmış ve aynı gün karara bağlanmış oldukları için, en büyük dava olan Yukos davası olarak anılmaktadırlar. Davanın büyüklüğü (Rusya'dan talep edilen miktar yaklaşık 114 milyar USD, karara bağlanan tazminat tutarı ise yaklaşık 50 milyar USD'dir), Rusya'nın dünya enerji piyasasında kazanmaya çalıştı̆̆ 1 rol, davanın seyri gibi nedenlerle Yukos hakkında akademik ve siyasi pek çok yayın ve haber bulmak mümkündür. 
başvurulur, üç aylık sürenin sona ermesiyle de Lahey Daimi Hakemlik Mahkemesi'ne gidilir ${ }^{43}$. Rusya Federasyonu EŞA'y1 17 Aralik 1994'te imzalamış ancak başvuru yapıldığı tarih itibariyle onaylamamış, üstelik EŞA md. 45(2)(b)'de yer alan geçici uygulamayacağı beyanında da bulunmamıştır. Davacı taraf(lar)ın iddiası Rusya Federasyonu EŞA'yı imzaladığı için geçici olarak uygulamak zorunda olduğu, Daimi Hakemlik Mahkemesi'nin EŞA uyarınca davaya bakmaya yetkili olduğu, Yukos (ve diğer şirketler) ile ilgili idari tasarrufların EŞA'nın ihlali anlamına geldiği ve zararlarının tazmin edilmesi gerektiğidir. Daimi Hakemlik Mahkemesi, 30 Kasım 2009 tarihinde verdiği kararla ${ }^{44}$ geçici uygulamaya ilişkin de önemli bir tartışma yapmak durumunda kalmıştır. Rusya’nın iddiasına göre, EŞA md. 45'te yer alan iç hukuka uygun olma, yani "sınırlama kaydı", Rusya'nın iç hukukuna uygun olmayan EŞA hükümlerini geçici olarak uygulama yükümlülüğü doğurmuyordu ${ }^{45}$. Mahkeme böyle parçalı bir uygulamanın söz konusu olamayacağına karar vermekle beraber, EŞA'daki sınırlama kaydının bütün bir andlaşmanın, yani EŞA'nın geçici olarak uygulanmasının Rus hukukuna uygun olup olmadı̆̆ıyla ilgili olduğuna karar vermiştir ${ }^{46}$. Aksi takdirde bu, iç hukukun uluslararası hukukun ihlali için bir mazeret olarak sunulamayacağı şeklindeki kuralın yok sayılması anlamına gelecektir ${ }^{47}$. Mahkeme bunun yanında önemli bir tespitte daha bulunarak, geçici uygulamanın bir uluslararası hukuk mekanizması olduğuna, sınırlama kayıtlarının yanlış yorumlanmasının iç hukukun uluslararası hukuku kontrol eder hale getireceğine, bunun da uluslararası ilişkilerde kabul edilemez bir belirsizliğe yol açacağına karar vermiştir $^{48}$. Mahkemeye göre Rus hukuku, EŞA'nın geçici olarak uygulanmasını kabul etmekte, bu da Rus devleti açısından yükümlülük doğurmaktadır ${ }^{49}$. Bu ara karardan sonra Mahkeme, 18 Haziran 2014'te,

${ }^{43}$ Alex. M. NIEGBRUEGGE, "Provisional Application of the Energy Charter Treaty: The Yukos Arbitration and the Future Place of Provisional Application in International Law", C. 8, Chicago Journal of International Law, 2007, s. 362-5.

${ }^{44}$ Yukos Universal Limited (Isle of Man) v. The Russian Federation, Interim Award on Jurisdiction and Admissibility, 30 Kasim 2009, UNCITRAL, PCA Case No. AA 227.

45 Yukos Universal Limited (Isle of Man) v. The Russian Federation, Interim Award on Jurisdiction and Admissibility, par. 294.

${ }^{46}$ Yukos Universal Limited (Isle of Man) v. The Russian Federation, Interim Award on Jurisdiction and Admissibility, par. 311.

${ }^{47}$ Yukos Universal Limited (Isle of Man) v. The Russian Federation, Interim Award on Jurisdiction and Admissibility, par. 312.

${ }^{48}$ Yukos Universal Limited (Isle of Man) v. The Russian Federation, Interim Award on Jurisdiction and Admissibility, par. 319.

${ }^{49}$ Yukos Universal Limited (Isle of Man) v. The Russian Federation, Interim Award on Jurisdiction and Admissibility, par. 394. 
Rusya'yı üç ayrı başvuru için toplamda 50 milyar USD tazminata mahkûm etmiştir ${ }^{50}$. Rusya bu karara karşı Lahey Bölge Mahkemesi’ne başvurmuştur. Lahey Bölge Mahkemesi ise, Rusya'nın geçici uygulama yükümlülügünü kabul etmekle birlikte, Daimi Hakemlik Mahkemesi'nin benimsediği tutumun tersine, bu sorumluluğun EŞA'nın sadece Rus hukukuyla uyumlu kısımları açısından söz konusu olduğuna karar vermiştir ${ }^{51}$. Bu tutum sonucunda da, EŞA'nın tahkime işaret eden hükümlerini Rus hukukuna uygun görmeyerek, Daimi Hakemlik Mahkemesi'nin yetkisizliğine karar vermiştir ${ }^{52}$.

\section{GEÇİCI UYGULAMA ANLAŞMASI}

Geçici uygulama, geçici uygulamaya dair bir anlaşmadan kaynaklanır $^{53}$. Bu anlaşma farklı şekillerde tezahür edebilir: Geçici uygulanacak andlaşmada bu yönde bir hüküm bulunabileceği gibi, andlaşmanın geçici uygulanacağına dair ayrı bir anlaşma akdedilebilir veya bu husus mektup teatisi yoluyla veya başka herhangi bir yolla hükme bağlanabilir. Ama her halükârda ortada geçici uygulamaya dair ayrı bir anlaşmanın var olduğunu kabul etmek gerekir ${ }^{54}$.

Andlaşmanın geçici uygulamaya dair hüküm içermesi durumunda, geçici uygulamaya dair hüküm 'andlaşmadan ayrık bir taahhüt' olarak tasavvur edilir. Bu durum, VAHS md. 24(4)'teki şu ifade ile uyumludur:

"Bir andlaşma metninin tevsiki, Devletlerin andlaşma ile bağlanma rızasının tespit edilmesi, yürürlüğe giriş tarzı veya tarihi, çekinceler, depoziter makamının işlevleri ve andlaşmanın yürürlüğe girmesinden önce zorunlu olarak ortaya çıkan diğer meseleleri düzenleyen hükümleri, andlaşma metninin kabulü zamanından itibaren uygulanır."

Bu hüküm çerçevesinde geçici uygulama, 'andlaşmanın yürürlüğe girmesinden önce zorunlu olarak ortaya çıkan diğer meseleleri düzenleyen hükümler' kapsamında değerlendirilir ${ }^{55}$.

\footnotetext{
${ }^{50}$ Yukos Universal Limited (Isle of Man) v. The Russian Federation, Final Award, 18 Temmuz 2014, UNCITRAL, PCA Case No. AA 227.

${ }^{51}$ Yukos Universal Limited (Isle of Man) v. The Russian Federation, Final Award, par. 5.23 .

52 Yukos Universal Limited (Isle of Man) v. The Russian Federation, Final Award, par. 5.95.

${ }^{53}$ MATHY, "1969 Vienna Convention - Article 25”, s. 649.

${ }^{54}$ MATHY, "1969 Vienna Convention - Article 25", s. 650.

${ }^{55}$ MATHY, “1969 Vienna Convention - Article 25”, s. 650; Toluner Milletleraras1 Hukuk (Giriş, Kaynaklar), s. 112.
} 
Geçici uygulama anlaşması, geçici uygulanacak andlaşmadan farklı bir anlaşmayla da hükme bağlanabileceği gibi herhangi bir şekilde de bu konuda fikir birliğine varılarak geçici uygulamanın hayata geçirilmesi mümkündür ${ }^{56}$. Andlaşmalara ekler veya protokoller de geçici uygulamayı konu edinebilir ${ }^{57}$. Devletler tek taraflı beyanlarla andlaşmayı geçici olarak uyguladıklarını ilan edebilecekleri gibi, bu yönde zımni bir uzlaşmadan bahsetmek bile mümkün olabilir ${ }^{58}$. Bunun yanında "büyük olan küçüğü de içerir" -in maiore minus- genel ilkesi uyarınca devletler geçici uygulamaya her zaman karar verebilirler ${ }^{59}$.

\section{GEÇİCI UYGULAMANIN SONA ERMESI}

Geçici uygulama, andlaşmayla bağlanmış olan devletler açısından andlaşmanın yürürlüğe girmesiyle birlikte sona erer. Artık andlaşma, bu devletler açısından geçici olarak uygulanmamaktadır; söz konusu devletler andlaşmanın tarafı olarak yürürlükte olan bir anlaşmayı uygulamaktadırlar. Bununla birlikte, özellikle çok taraflı andlaşmalarda, andlaşma andlaşmayla bağlı devletler açısından yürürlüğe girmiş olsa bile, andlaşmayı imzalamış olmakla birlikte gerekli iç hukuk prosedürünü tamamlamadığı ve, eğer varsa, andlaşmanın kendisi açısından yürürlüğe gireceği süre henüz geçmediği için andlaşmanın kendileri açısından yürürlüğe girmediği devletler söz konusudur. Böyle bir durumda andlaşmanın, henüz andlaşmayla bağlanmamış devletin kabul ettiği bir geçici uygulama kaydı varsa andlaşma yürürlüğe girmiş olsa bile, andlaşmanın kendisi açısından yürürlüğe girmediği devlet için geçici uygulama devam edecektir ${ }^{60}$. Özetle, VAHS md. 25 'te yer alan ve uluslararası andlaşmalarda kendisine yer bulan 'andlaşma yürürlüğe girinceye dek' ifadesindeki yürürlüğe girme, andlaşmanın ilk onaylayanlar eliyle yürürlüğe girmesinden değil ama her bir ilgili devlet açısından yürürlüğe girmiş olma anlamına gelmektedir.

VAHS md. 25'in ikinci fikrasına göre, "Andlaşma başka türlü öngörmedikçe veya görüşmeci Devletler başka türlü mutabık kalmadıkça, bir andlaşmanın veya bir andlaşmanın bir bölümünün bir Devlet bakımından uygulanmasına, o Devlet, aralarında geçici olarak

\footnotetext{
56 MATHY, "1969 Vienna Convention - Article 25", s. 650; LEFEBER, "Treaties, Provisional Application", par. 6.

${ }^{57}$ KRIEGER, “Article 25”, s. 414.

${ }^{58}$ MATHY, "1969 Vienna Convention - Article 25", s. 651.

${ }^{59}$ VILLIGER, Commentary on the $1969 \ldots$, s. 354.

${ }^{60}$ KRIEGER, "Article 25", s. 416; LEFEBER, "Treaties, Provisional Application", par. 10; Anthony AUST, Modern Treaty Law and Practice, 6. bask1 (Cambridge: CUP, 2016), s. 154.
} 
andlaşmanın uygulandığı diğer Devletleri andlaşmaya taraf olmamak hususundaki niyetinden haberdar ederse, son verilecektir". Bu hüküm özellikle iç hukuku uyarınca gerekli prosedür sonucu andlaşmayla bağlanma iradesi ortaya çıkmayan devlet için bir koruma sağlamaktadır ${ }^{61}$. $\mathrm{Bu}$ hüküm çerçevesinde sona eren geçici uygulama, sadece taraf olmama iradesini bildiren devlet açısındandır. Diğer devletler açısından söz konusu olan geçici uygulama, bu devletin beyanından etkilenmez ${ }^{62}$.

Bununla birlikte VAHS'nin bu hükmünün geçici uygulamadan vaz geçme veya geçici uygulamayı kabul etmeme yönünde açık bir nokta bıraktığını söylemek gerekmektedir. Zira, eğer aksi andlaşmada öngörülmemişse, VAHS'ye göre bir devletin andlaşmayla bağlanma iradesini ifade etmeksizin geçici uygulamayı kabul etmemesi söz konusu olmamaktadır. Dolayısıyla VAHS uyarınca bir devletin geçici uygulama kaydı olan bir andlaşmada iç hukukunca gerekli prosedürleri yerine getirene dek geçici uygulamaya tabi olmama usulüne dair herhangi bir şey bulmak mümkün değildir. Nitekim yukarıda değindiğimiz hakemlik kararlarında ortaya çıkan tartışma konularından birisi, ilgili andlaşmanın (EŞA) geçici uygulama ile ilgili hükümleri kadar VAHS'deki belirsizliktir.

Devletlerin geçici uygulamanın sona ermesine dair hüküm koyması da mümkündür. Sözgelimi Açı Semalar Antlaşması'nın ${ }^{63}$ XVIII. maddesinde hükme bağlanan geçici uygulama bu şekildedir:

"Bu geçici uygulama, bu Antlaşma'nın imzaya açıldığı tarihten sonraki 12 aylık dönem boyunca geçerli olacaktır. Geçici uygulama döneminin sona ermesinden önce bu Antlaşma'nın yürürlüğe girmemesi durumunda, sözkonusu dönem tüm imzacı Devletler karar verdikleri takdirde uzatılabilir. Herhalükarda, geçici uygulama dönemi bu Antlaşma'nın yürürlüğe girmesiyle birlikte son bulacaktır. Ancak, Taraf Devletler, bu Antlaşma'yı onaylamamış olan imzacı Devletler bakımından geçici uygulama dönemini uzatmaya karar verebilirler."

Açık Semalar Antlaşması'nın 1992'den 2002'deki yürürlüğe girene dek tümüyle geçici olarak uygulandığgn $1{ }^{64}$ da not etmemiz gerekiyor.

\footnotetext{
${ }^{61}$ VILLIGER, Commentary on the $1969 \ldots$, s. 355.

${ }^{62}$ VILLIGER, Commentary on the $1969 \ldots$... s. 355.

${ }^{63}$ Açı Semalar Antlaşması - Open Skies Treaty, 24 Mart, 1992, R.G., T. 9.4.1994, S. 21900.

${ }^{64}$ AUST, Modern Treaty Law and Practice, s. 155.
} 


\section{GEÇICI UYGULAMA ANLAŞMASININ BAĞLAYICILIĞI VE HUKUKI SONUÇLARI}

Uluslararası hukuk literatürünün ağırlıklı olarak geçici uygulamanın uluslararası hukuk açısından bağlayıcı olduğu, devletin sorumluluğunu doğurduğu, geçici uygulamaya tabi olan andlaşmanın hüküm doğuracağ düşüncesinde olduğu söylenebilir ${ }^{65}$. Bu görüş, ağırlıklı olarak, geçici uygulamanın doğurduğu bağlayıcılığın, tıpkı yürürlükteki andlaşmanın doğurduğu sorumluluk gibi olduğunu iddia eder. Mertsch, VAHS'nin hazırlık sürecinde UHK'de ve Viyana Konferası'nda yapılan tartışmalara atıf yaparak bu yaklaşımın sorunlu olduğunu, artık itibar edilmemesi gereken bir 'yürürlük' ve 'uygulama' denkliğine dayandığını söyler ${ }^{66}$.

Yukarıda da belirtildiği gibi, geçici uygulama anlaşması, tek başına farklı bir anlaşma olarak görülmek durumundadır ${ }^{67}$. Bu hâliyle geçici uygulama anlaşması, uluslararası hukuk açısından bağlayıcılık doğuran bir metin olarak karşımıza çıkar ${ }^{68}$. Ancak Mertsch bu yaklaşımın da sorunlu olduğunu, çünkü andlaşmaların bağlayıcı olduğuna dair zaten bir ön kabul olduğunu, asıl sorunun geçici uygulamanın bunun bir istisnası olup olmayacağının açık şekilde ortaya koyulması olduğunu savunur ${ }^{69}$. Ona göre geçici uygulamanın uluslararası hukuk açısından teorik konumu belirsizliklerle doludur ve devlet uygulaması pragmatik amaçlarla şekillendirilmiştir. Bazı andlaşma türlerinde geçici uygulama kaydının mutlak surette uluslararası yükümlülük yaratma amacını taşıdığı rahatlıkla tespit edilmekle birlikte bazı andlaşmalarda bunu söylemek mümkün değildir $^{70}$.

Mathy, geçici uygulama ile iç hukuk arasında çıkan çatışmalar nedeniyle ortaya çıkan uyuşmazlık sayısının azlığına dikkat çekerken, bunun nedeni olarak devletlerin daha sonra onayını alamayacakları taahhütlerin altına girme konusunda oldukça dikkatli hareket etmelerini gösterir ${ }^{71}$. Ortada bir anlaşma bulunduğuna göre, VAHS'nin 'Ahde vefa (pacta sund servanda)' başlığını taşıyan 26. maddesinin 'Yürürlükteki her

${ }^{65}$ KRIEGER, “Article 25”, s. 420; MATHY, “1969 Vienna Convention - Article 25”, s. 646; LEFEBER, "Treaties, Provisional Application", par. 16; DALTON, "Provisional Application of Treaties", s. 245.

${ }^{66}$ MERTSCH, Provisionally Applied Treaties..., s. 120-7.

${ }^{67}$ MATHY, "1969 Vienna Convention - Article 25", s. 650.

${ }^{68}$ MERTSCH, Provisionally Applied Treaties..., s. 140.

${ }^{69}$ MERTSCH, Provisionally Applied Treaties..., s. 142.

${ }^{70}$ MERTSCH, Provisionally Applied Treaties..., s. 231-33.

${ }^{71}$ MATHY, "1969 Vienna Convention - Article 25", s. 646. DALTON da bu hususa, geçici uygulamanın suiistimaline dair endişe bildirenlerin görüşlerinin yersizliğine vurgu yaparken dikkat çeker. Bkz. DALTON, "Provisional Application of Treaties", s. 241. 
andlaşma ona taraf olanları bağlar ve taraflartn onu iyi niyetle icra etmesi gerekir" hükmü uyarınca, devletlerin geçici uygulamaya ile yüklendikleri yükümlülükleri yerine getirmeleri gerekmektedir.

Bununla birlikte geçici uygulamanın devletler açısından bağlayıcı olmadığına dair görüşler de mevcuttur. Bu görüşler bilhassa 'sınırlama kaydı' bulunan geçici uygulamada belirleyici olanın 'iç hukuk' olduğunu söyler. Bu çerçevede geçici uygulamanın bir 'soft law' örneği olduğu, dolayısıyla ancak sınırlı ölçüde hukuki sonuç doğuracağı dile getirilir. VAHS md. 25(2)'de yer alan, geçici uygulamadan tek taraflı vaz geçebilme hükmü de, geçici uygulamanın yarattı̆̆ iddia edilen hukuki yükümlülüklerin zayıflığına delil olarak gösterilir ${ }^{72}$. Nitekim yukarıda iki örneğini gördüğümüz bazı davalarda devletler geçici uygulamanın sorumluluk doğurmadığını iddia etme yoluna da gitmişlerdir. Ancak devlet pratiğinin geçici uygulamanın hukuk hak ve yükümlülükler yarattığını tasdik ettiğini söylemek yanlış olmaz ${ }^{73}$. Bunun yanında VAHS'de de ifadesini bulmuş bir uluslararası hukuk kuralı olarak, "Bir taraf bir andlaşmayı icra etmeme gerekçesi olarak iç hukukunun hükümlerine başvuramaz". Yine de, 'sadece' geçici olarak uygulanan andlaşmaların meşruiyet ve hukuki belirlilik açısından eksik kaldığını da eklemek gerekmektedir ${ }^{74}$.

Geçici uygulama anlaşmasının, devletlerin andlaşmayla bağlanma iradesiyle ilişkisi yoktur. Daha önce de belirttiğimiz gibi bir devlet bir andlaşmayı imzalamak suretiyle geçici uygulamayı kabullendiği hâlde söz konusu andlaşmayla bağlanma yoluna gitmeyebilir. Bu açıdan geçici uygulamayı kabul etmiş olmak, bağlanma yönünde bir vaat anlamı taşımaz. Bu açıdan geçici uygulama anlaşması için andlaşmayla bağlanma rızası da aranmamış olur ${ }^{75}$.

\section{UHK' NIN GEÇICI UYGULAMA HAKKINDAKI MEVCUT ÇALIŞMASI}

UHK, 2011'deki altmış üçüncü döneminde "Andlaşmaların Geçici Uygulanması" konusunu uzun dönem çalışma programına dahil etme kararı almışıır ${ }^{76}$. Giorgio Gaja'nın karara ekli raporu, geçici uygulama

\footnotetext{
72 Geçici uygulamanın hukuken bağlayıcı olmadığı, daha doğrusu hukuki olmayan bir bağlayıcılığg olduğu yönündeki görüşlerin ayrıntılı bir analizi için bkz. MERTSCH, Provisionally Applied Treaties..., s. 73-118.

${ }^{73}$ KRIEGER, "Article 25”, s. 420.

${ }^{74}$ KRIEGER, “Article 25”, s. 420.

${ }^{75}$ MERTSCH, Provisionally Applied Treaties..., s. 14.

${ }^{76}$ Report of the International Law Commission, Sixty-third session, A/66/10, par. 365. İnternet erişimi: $<\mathrm{http}$ ://legal.un.org/docs/?symbol=A/66/10> (03.07.2018).
} 
çerçevesinde ortaya çıkan bazı sorunlara işaret eder. Gaja'nın sunduğu rapora göre, UHK'nin konuyu değerlendirmesi ihtiyac1; (1) VAHS'de geçici uygulamanın tanımının yapılmamasının geçici uygulamanın bağlayıcılığı açısından belirsizlik yaratmasından, (2) Yukos gibi hakemlik kararlarında ortaya çıkan uyuşmazlıkların VAHS'deki belirsizlikle ilişkili olmasından ve (3) VAHS'nin, andlaşmayla bağlanmama iradesini belirtmemiş devletlerin geçici uygulamayı reddetmelerine dair daha önce de değinilen boşluktan kaynaklanmaktadır ${ }^{77}$.

UHK'nin 2012'deki dördüncü döneminde ise, konu çalışma programına dahil edilerek Juan Manuel Gómez-Robledo özel raportör olarak atanmıştır. Özel raportör 20 Şubat 2018 itibariyle beşinci raporunu sunmuştur $^{78}$. UHK'nin çalışması sürecinde geçici uygulamanın halihazırdaki durumu üzerine tespitlerde bulunulmuş, geçici uygulamaya dair devlet pratiği incelenmiş, uluslararası andlaşmalarda bulunan geçici uygulama hükümlerinin dökümü yapılmış, geçici uygulama ile VAHS'nin ilişkili olabilecek hükümleri arasındaki bağlantı analiz edilerek bu hükümlerle ilgili kılavuz hükümlerin hazırlanmasına başlanmış ve üye devletlere konuyla ilgili görüşleri sorularak alınan yanıtlar değerlendirilmiştir. Nihayetinde özel raportörün son raporu olan beşinci raporda, uluslararası andlaşmalarda kullanılabilecek model hükümler geliştirilmiştir. $\mathrm{Bu}$ model hükümlerle, uluslararası andlaşmalarda yer alacak geçici uygulama hükümlerinin daha belirli ve daha az ihtilafa yol açacak biçime büründürülmesi amaçlanmıştır. Bu model hükümler, geçici uygulamanın (1) başlamasına, (2) sona ermesine ve (3) geçici uygulamanın kapsamına ilişkin olarak, farklı olasılıklar da düşünülerek toplam sekiz adettir.

UHK'nin, Özel Raportör'ün beşinci raporunda, geçici uygulamanın başlangıcına dair önerdiği dört model hüküm şu şekildedir ${ }^{79}$ :

"1. model hüküm:

Müzakereci [âkit] ${ }^{80}$ Devletler [uluslararası örgütler] bu Andlaşmayı imza tarihinden (veya mutabık kalınacak herhangi bir tarihten) itibaren geçici olarak uygulama konusunda anlaşmışlardır.

\footnotetext{
${ }^{77}$ Provisional Application of Treaties (Mr. Giorgio Gaja), A/66/10, Annex C.

78 Juan Manuel GÓMEZ-ROBLEDO, Fifth Report on the Provisional Application of Treaties, BMGK, A/CN.4/718 <http://legal.un.org/docs/?symbol=A/CN.4/718> (03.07.2018).

${ }^{79}$ GÓMEZ-ROBLEDO, Fifth Report on the Provisional Application of Treaties, par. 7377.

${ }^{80}$ Model hüküm çevirilerindeki köşeli ayraçlar metnin orijinalinde bulunmaktadır.
} 
2. model hüküm:

Müzakereci [âkit] Devletler [uluslararası örgütler] bu Andlaşmayı [belirli bir tarihten] itibaren geçici olarak uygulama konusunda anlaşmışlardır.

3. model hüküm:

Müzakereci [âkit] Devletler [uluslararası örgütler] bu Andlaşmayı [Andlaşmanın ... maddelerini] geçici olarak uygulama konusunda anlaşmışlardır. Böyle bir geçici uygulamaya razı olmadığını imza esnasında Depozitör'e haber veren Devletler [uluslararası örgütler] bu durumdan müstesnadır.

4. model hüküm:

$\mathrm{Bu}$ Andlaşma, bir Devletin [bir uluslararası örgütün] ilgili diğer Devletleri [uluslararası örgütleri] haberdar ettiği veya Depozitör'e bu sonucu doğurmak üzere bir beyanda bulunduğu tarihten itibaren geçici olarak uygulanacaktır."

UHK'nin, Özel Raportör'ün beşinci raporunda, geçici uygulamanın sona ermesine dair önerdiği iki model hüküm şu şekildedir:

"5. model hüküm:

$\mathrm{Bu}$ andlaşmanın geçici olarak uygulanması, andlaşmanın, andlaşmayı geçici olarak uygulamakta olan bir Devlet [uluslararası örgüt] bakımından yürürlüğe girmesiyle sona erer.

6. model hüküm:

$\mathrm{Bu}$ Andlaşmanın bir Devlet [uluslararası örgüt] açısından geçici olarak uygulanmas1, bu Devlet [uluslararas1 örgüt] diğer Devletleri [uluslararası örgütleri] (veya Depozitör'ü) Andlaşma ile bağlanmayacağı niyetini bildirdiği takdirde sona erer."

UHK'nin, Özel Raportör'ün beşinci raporunda, geçici uygulamanın kapsamına dair önerdiği iki model hüküm şu şekildedir:

"7. model hüküm:

Diğer Devletlere [uluslararası örgütleri] (veya Depozitör'ü) Andlaşmayı geçici olarak uygulayacağını bildiren Devlet [uluslararası örgüt] ilgili Devletlerin [uluslararası örgütlerin] mutabık kaldığ1 bütün hükümlere uymakla yükümlüdür.

8. model hüküm:

Diğer Devletlere [uluslararası örgütleri] (veya Depozitör'ü) Andlaşma'nın [....] maddelerini geçici olarak uygulayacağını bildiren Devlet [uluslararası örgüt] ilgili Devletlerin [uluslararası örgütlerin] mutabık kaldığı bütün hükümlere uymakla yükümlüdür." 
UHK'nin andlaşmaların geçici uygulanması ile ilgili çalışması devam etmektedir. Hem geçici uygulamanın VAHS'nin diğer hükümleriyle olan ilişkisi hakkındaki kılavuz hükümlerin hazırlığı gerekse de alıntıladığımız bu model hükümler üzerindeki okuma ve değerlendirme çalışmaları henüz tamamlanmamıştır. Ancak bu hâliyle bile çalışma, geçici uygulamadan doğan sorunlara ilişkin bir fikir vermektedir.

\section{SONUÇ}

VAHS'nin 25. maddesi iç hukukta gerekli işlemlerin tamamlanmaması nedeniyle henüz yürürlüğe girmemiş bir andlaşmanın tamamının veya bir kısmının tarafların mutabakatıyla geçici olarak uygulanabileceğini öngörmektedir. Bu hüküm kaynağını uluslararası örf ve adet hukukundan almaktadır. Nitekim gerek tarihsel olarak gerekse de VAHS sonrasında iki ve çok taraflı andlaşmalarda geçici uygulama kaydı içeren andlaşmaların akdedildiği görülmektedir.

Tarafların andlaşmanın iç hukukta da kabul edileceğine kesin güven duyduğu ve barış andlaşmaları gibi aciliyet gerektiren hususlarda geçici uygulama konusunda ihtilaf çıkmamakla birlikte, çok taraflı andlaşmaların uygulanmasında bazı ihtilaflarla karşılaşılabilmektedir. Geçici uygulama genel olarak kabul gördüğü şekliyle geçici uygulamayı kabul etmiş, en azından itiraz etmemiş devletler açısından hukuki sorumluluk doğurmaktadır. Ortaya çıkan ihtilaflar, VAHS md. 25 ve buna paralel hazırlanan andlaşma hükümlerindeki bazı belirsizlikler nedeniyle sorumluluk tartışmalarına yol açmaktadır. Nitekim Uluslararası Hukuk Komisyonu, VAHS'deki bağlayıcılık ruhuna uygun olarak, uygulamada bu belirsizliklerin giderilmesi amacıyla bir çalışma yürütmektedir. Çalışmanın ortaya koyduğu üzere, VAHS'nin geçici uygulamaya ilişkin hükümlerinin genel anlamı konusunda bir anlaşmazlık bulunmamakta ancak devletler arasında yapılacak andlaşmalardaki geçici uygulama hükümlerinin olası uyuşmazlıkları önceden bertaraf etmek için daha açık bir şekilde düzenlenmesine ihtiyaç bulunmaktadır.

\section{KAYNAKÇA}

\section{Kitap, Kitap Bölümü ve Makaleler}

ACER, Yücel ve İbrahim KAYA (2015). Uluslararası Hukuk Temel Ders Kitabı, 6. bask1 (Ankara: Seçkin Yayıncılık).

AKSAR, Yusuf (2015). Teoride ve Uygulamada Uluslararas1 Hukuk - I, 3. bask1 (Ankara: Seçkin Yayıncılık).

AUST, Anthony (2016). Modern Treaty Law and Practice, 6. bask1 (Cambridge: CUP).

BAKLACI, P. ve E. AKINTÜRK, "Enerji Şartı Anlaşması", Dokuz Eylül Üniversitesi İşletme Fakültesi Dergisi, C. 7, S. 2, 2006, ss. 97-113. 
BELZ, Matthew (2008). "Provisional Application of the Energy Charter Treaty: Kardassopoulos v. Georgia and Improving Provisional Application in Multilateral Treaties", C. 22, Emory International Law Review, ss. 727-60.

BOZKURT, Enver, M. Akif KÜTÜKÇÜ ve Yasin POYRAZ (2012). Devletler Hukuku, 7. bask1 (Ankara: Yetkin Yayınları).

CRAWFORD, James (2012). Brownlie's Principles of Public International Law, 8. bask1 (Oxford: OUP).

DALTON, Robert E. (2012). "Provisional Application of Treaties", The Oxford Guide to Treaties, Ed.: Duncan B. HOLLIS (Oxford: OUP), ss. 220-47.

KAYA CANER, Bağdagül (2014). "Enerji Şartı Anlaşmasının Muvakkaten Uygulanması ve Anlaşmadan Çekilme Hakkında Bir Değerlendirme", Ankara Barosu Dergisi, 2014/3, ss. 314-32.

KAYA, İslam Safa (2016). "Uluslararası Andlaşmalardan Çekilme Hakkı ve Uluslararası Andlaşmaların Geçici Uygulanması: Enerji Şartı Andlaşması Örneği”, The Journal of Academic Social Science Studies, N. 44, Spring II, s. 193-201.

KRIEGER, Heike (2012). "Artice 25”, Vienna Convention on the Law of Treaties, Ed.: O. DÖRR ve K. SCHMALENBACH (Berlin-Heidelberg: SpringerVerlag), ss. 407-421.

LEFEBER, René (2012). "Treaties, Provisional Application", The Max Planck Encyclopedia of Public International Law, C. X, Ed.: R. WOLFRUM (Oxford: OUP), ss. 1-5.

MATHY, Denise (2011). "1969 Vienna Convention - Article 25", The Vienna Conventions on the Law of Treaties, Ed.: O. CORTEN ve P. KLEIN (Oxford: OUP), ss. 639-56.

MERTSCH, Anneliese Quest (2012). Provisionally Applied Treaties: Their Binding Force and Nature (Lieden ve Boston: Brill).

NIEGBRUEGGE, Alex. M. (2007). "Provisional Application of the Energy Charter Treaty: The Yukos Arbitration and the Future Place of Provisional Application in International Law", C. 8, Chicago Journal of International Law, ss. 355-76.

PAZARCI, Hüseyin (2014). Uluslararası Hukuk Dersleri - 1. Kitap, 12. baskı (Ankara: Turhan Kitabevi).

ROGOFF, Martin A. ve Barbara E. GAUDITZ (1987). "The Provisional Application of International Aggreements", Maine Law Review, C. 39, ss. 29-81.

TÜTÜNCÜ, A.N. vd., Ed. (2017). Toluner Milletlerarası Hukuk (Giriş, Kaynaklar) (İstanbul: Beta, 2017).

VILLIGER, Mark. E. (2009). Commentary on the 1969 Vienna Convention or the Law of Treaties (Lieden ve Boston: Martinus Nijhoff Publishers).

\section{Andlaşmalar, Kararlar ve Raporlar}

Açık Semalar Antlaşması - Open Skies Treaty, 24 Mart, 1992, R.G., T. 9.4.1994, S. 21900. Avrupa'da Konvansiyonel Silahlı Kuvvetler Antlaşması'nın Bazı Hükümlerinin Geçici Olarak Uygulanması Hakkındaki Protokol, R.G. 26.6.1992, S. 21266. Metin için bkz. <https://www.tbmm.gov.tr/tutanaklar/KANUNLAR_KARARLAR/kan untbmmc075/kanuntbmmc075/kanuntbmmc07503818.pdf> (12.06.2018). 
Enerji Şartı Anlaşması - Energy Charter Treaty (ECT), 17 Aralık 1994, Lizbon. Türkiye Anlaşma'nın tarafıdır: R.G. 12 Temmuz 2000, S. 24107. Orijinal metin için bkz. Energy Charter Secretariat, The Energy Charter Treaty and Related Documents, 2004, Belçika. İnternet erişimi: <http://www.ena.lt/pdfai/Treaty.pdf > (404.07.2018).

Gómez-Robledo, Juan Manuel, First Report on the Provisional Application of Treaties, BMGK A/CN.4/664 <http://undocs.org/en/A/CN.4/664> (12.06.2018).

Gómez-Robledo, Juan Manuel, Fifth Report on the Provisional Application of Treaties, BMGK, 2018 ,

A/CN.4/718 $<$ http://legal.un.org/docs/?symbol=A/CN.4/718> (03.07.2018).

Kardassopoulos v. Georgia, Decision on Jurisdiction, 6 Temmuz 2007, ICSID (W. Bank), Case No. ARB/05/18. İternet erişimi: $<$ https://www.italaw.com/sites/default/files/casedocuments/ita0444.pdf> (29.06.2018).

Nükleer Kaza Halinde Erken Bildirim Sözleşmesi, R.G., T. 03.09.1990, S. 20624. Metin için bkz. <https://www.tbmm.gov.tr/tutanaklar/KANUNLAR_KARARLAR/kan untbmmc073/kanuntbmmc073/kanuntbmmc07303610.pdf> (12.06.2018).

Nükleer Kaza veya Radyolojik Acil Hallerde Yardımlaşma Sözleşmesi, R.G., T. 03.09.1990, S. 20624. Metin için bkz. <https://www.tbmm.gov.tr/tutanaklar/KANUNLAR_KARARLAR/kan untbmmc073/kanuntbmmc073/kanuntbmmc07303610.pdf> (12.06.2018).

Report of the International Law Commission, Sixty-third session, A/66/10, par. 365. İnternet erişimi: $\quad<$ http://legal.un.org/docs/?symbol=A/66/10> (03.07.2018).

Viyana Andlaşmalar Hukuku Sözleşmesi - Vienna Convention on the Law of Treaties, 1969. Türkçesi: Aslan Gündüz, Milletlerarası Hukuk (İstanbul: Beta Basim Yayım, 1998), ss. 182-205. Orijinal metin: <https://treaties.un.org/doc/publication/unts/volume\%201155/volume1155-i-18232-english.pdf> (03.07.2018).

1986 Viyana Devletlerle Uluslararası Örgütler veya Uluslararası Örgütlerle Uluslararası Örgütler Arasındaki Andlaşmalar Hukuku Sözleşmesi - Vienna Convention on Treaties between States and International Organizations or between International Organizations (1986), U.N. Doc. A/CONF.129/15 (1986). Internet erişimi: <http://legal.un.org/ilc/texts/instruments/english/conventions/1_2_198 6.pdf $>(06.07 .2018)$.

Yukos Universal Limited (Isle of Man) v. The Russian Federation, Interim Award on Jurisdiction and Admissibility, 30 Kasim 2009, UNCITRAL, PCA Case No. AA 227. İnternet erişimi: <https://www.italaw.com/sites/default/files/casedocuments/ita0910.pdf> (29.06.2018).

Yukos Universal Limited (Isle of Man) v. The Russian Federation, Final Award, 18 Temmuz 2014, UNCITRAL, PCA Case No. AA 227. İnternet erişimi: <https://www.italaw.com/sites/default/files/casedocuments/italaw3279.pdf> (29.06.2018). 
